\title{
SHADOWING AND LISTENING COMPREHENSION OF ENGLISH-MAJOR STUDENTS
}

Nguyen Thi Minh Thao", Nguyen Van Tuong

Hanoi University of Industry

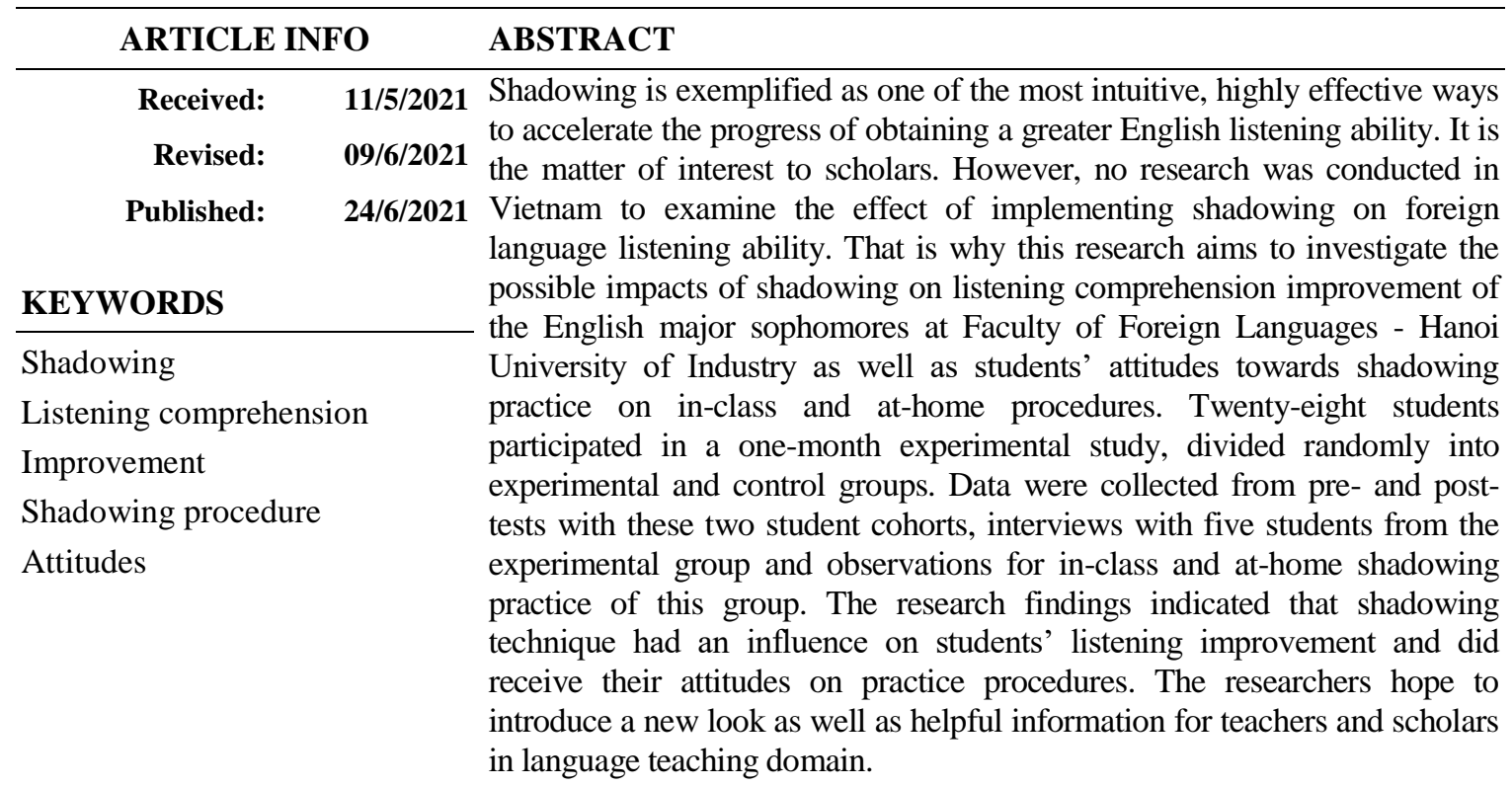

\section{PHƯONG PHÁP SHADOWING VÀ NĂNG LỰC NGHE HIỂU CỦA SINH VIÊN CHUYÊN NGÀNH NGÔN NGŨ๋ ANH \\ Nguyễn Thị Minh Thảo*, Nguyễn Văn Tưởng \\ Truoòng Đại học Công nghiệp Hà Nội}

\begin{tabular}{|c|c|c|}
\hline \multicolumn{2}{|c|}{ THÔNG TIN BÀI BÁO } & \multirow{4}{*}{$\begin{array}{l}\text { TÓM TÁ̆T } \\
\text { Shadowing được ví như một trong những kỹ thuật trực quan nhất, hiệu quả } \\
\text { nhất để nâng cao năng lực nghe tiếng Anh. Đây là vẩn đề được các học giả } \\
\text { quan tâm. Tuy nhiên, chưa có nghiên cứu nào được thực hiện ở Việt Nam }\end{array}$} \\
\hline Ngày nhận bài: & & \\
\hline & & \\
\hline Ngày hoản & 09/6/202 & \\
\hline Ngày đăng: & 24/6/2021 & để xem xét hiệu quả của kỹ thuật này đối với năng lực nghe ngoại ngữ. Do \\
\hline & & đó, các tác giả tiến hành nghiên cứu những tác động của kỹ thuật shadowing \\
\hline \multicolumn{2}{|l|}{ TÙ KHÓA } & nhằm tăng khả năng nghe hiểu của sinh viên năm thứ hai chuyên ngành \\
\hline \multicolumn{2}{|l|}{ Kỹ thuật shadowing } & $\begin{array}{l}\text { tieng Anh tạı Khoa Ngoạı ngư, trương Đậ học Cong nghıẹp Ha Nộ. } \\
\text { Nghiên cứu cũng nhằm tìm hiểu mức độ hài lòng của sinh viên đối với việc }\end{array}$ \\
\hline \multicolumn{2}{|l|}{ Khả năng nghe hiểu } & áp dụng quy trình thực hành kỹ thuật shadowing trên lớp và ở nhà. Hai \\
\hline \multicolumn{2}{|l|}{ Cải thiện } & iên tham gia vào nghiên cứu thực nghiệm kéo dài trong một \\
\hline \multicolumn{2}{|l|}{$\begin{array}{l}\text { Quy trình thực hành } \\
\text { shadowing }\end{array}$} & $\begin{array}{l}\text { tháng, được chia ngâu nhiên thành các nhóm thực nghiệm và nhóm đôi } \\
\text { chứng. Dữ liệu được thu thập từ các bài kiểm tra trước và sau với hai nhóm } \\
\text { siênh viên nàv }\end{array}$ \\
\hline \multirow{5}{*}{\multicolumn{2}{|c|}{ Thái độ }} & sát quá trình thực hành shadowing tại lớp và ở nhà của nhóm này. Kết quả \\
\hline & & nghiên cứu chỉ ra rằng kỹ thuật shadowing có ảnh hưởng đến việc cải thiện \\
\hline & & khả năng nghe của sinh viên, đồng thời sinh viên cho thấy thái độ tích cực \\
\hline & & đối với các quy trình thực hành shadowing. Các tác giả hy vọng mang đến \\
\hline & & $\begin{array}{l}\text { thông tin bồ ích và một cái nhìn rõ nét hơn về kỹ thuật shadowing cho giảng } \\
\text { viên và học giả trong lĩnh vực giảng dạy ngôn ngữ. }\end{array}$ \\
\hline
\end{tabular}

DOI: $\underline{\text { https://doi.org/10.34238/tnu-jst.4478 }}$

\footnotetext{
* Corresponding author. Email: thaontm@haui.edu.vn
} 


\section{Introduction}

Listening comprehension is always on top of the most important skills affecting the English standard of learners. However, most of English learners today do not frequently come up with certain strategy for listening skills or fail to consistently follow an effective and simple method, which evokes a picture that attaining better English listening skills is such an unreachable target. According to Anderson and Lynch [1], listening comprehension was highlighted as "understanding is not something that happens because of what a speaker says, the listener has a crucial part to play in the process, by activating various types of knowledge, and by applying what he knows to what he hears and trying to understand what the speaker means". Rost [2] confirmed listening comprehension as "catching what the speaker says". However, he believed that understanding all what speaker delivers was not an easy task as "listening is a transient and invisible process that cannot be observed directly, we need indirect descriptions". Therefore, it is clear that to attain a good listening, listeners are required to have the ability to decode the message and analyze the information, the ability to use different strategies to create meaning, and the ability to respond to what is said in various ways.

Some decisive aspects rubbing on the understanding of listener including characteristics of listener (psychology and concentration), characteristics of passage (length, complexity, organization and auditory features) and characteristics of the conditions during listening process (especially time limitation to response in the test). Additionally, cultural differences are one of the giant obstacles for L2 listeners to grab their heads around. The listeners may find strange and puzzled in dealing with materials about culture of other countries or other regions that they have no idea about them [3].

When it comes to methods of improving English listening comprehension skills, shadowing is exemplified as one of the most intuitive, highly effective ways to accelerate the progress of obtaining a greater English listening ability. Lambert [4] originally defined shadowing as a paced, auditory track in parrot-style, the repetition in word-for-word in one language, of a piece of information through the headphones. However, Hamada [5] claimed "shadowing should not be regarded as just repetition of phonetics" in favor of a highly cognitive activity. In shadowing, learners follow the heard speech and imitate the voice of speakers as clearly as possible while simultaneously listening [6].

By applying shadowing, students can gain benefits in several ways. Firstly, shadowing practicing activity helps to activate the bottom-up processing at micro level, and then information is passed on for macro-level analysis. Secondly, echoic memory, which information is stored in a short period by hearing, is activated to save information precisely [7]. Following these perspectives of shadowing, repetition or imitation is the core of this method, which practically exerts a strong impact to human memory and cognition.

By assessing the problems that English listeners normally struggle to, many researchers conducted studies to figure out effectiveness of shadowing on enhancing listeners' vocabulary size; increasing listeners' familiarity with different accents, speed and topics [8] - [12] and improving self-confidence and motivation [13]. It seems that shadowing is a perfect solution for both lingual and psychological problems that listeners normally confront with. Therefore, the authors in this research highly desire to examine whether shadowing practice is effective to her sophomores at Faculty of Foreign Languages, Hanoi University of Industry (FFL, HaUI) and how to adequately and successfully optimize shadowing's effect on these participants.

Despite of its effectiveness proven by a number of studies, many students have no idea about what shadowing is or how to apply it correctly. Being aware that shadowing is a useful tool that greatly helps students consequently accelerate the English listening ability in a very short period of time, this study aims (1) to evaluate the effectiveness of shadowing in improving English listening comprehension skill of the second-year major students at FFL, HaUI and (2) to 
investigate students' attitudes towards suggested in-class and at-home shadowing procedures. To reach this goal, the study addressed the following questions: (1) To what extent can second-year English major students at HaUI improve their listening comprehension skill by shadowing? and (2) What are students' attitudes towards the suggested in-class and at-home shadowing procedures? To answer these two questions, next parts of the study will offer an insight about research method, experiment together with discussion.

\section{Research methodology}

\subsection{Research setting and participants}

The participants of the study are 28 second-year English students at FFL, HaUI, including 4 males and 24 females. They were randomly chosen to take part in the tests. The reasons to select second-year English major students are as follows: Second-year English majors embark to learn IELTS training programs, which is somehow intricate for them to be familiar with. Besides, it seems that nearly almost of second-year English majors at HaUI do not acquire any self-training schedules, especially when it comes to listening comprehension skills. Hence, it is vital to introduce a substantial, practical learning strategy for second-year English students to reach other goals when they turn into seniors.

Participants are randomly separated into two groups, experimental group and control group. The ones in the experimental group undergo shadowing training within one month before taking the post-test to demonstrate the effectiveness of shadowing on listening comprehension skills. On the other hand, the others in control group are supposed to take part in two tests and their results are compared to those of experimental group afterwards.

\subsection{Research instruments}

A mixed research approach was applied with experimental method, interview and observation. Quantitative data from pre-test and post-test was used to partly answer for the question whether shadowing is effective to improve listening comprehension for sophomores at FFL, HaUI. Qualitative data from interview and observation provided better outlook to assess students' satisfaction on shadowing procedure applied in the research. The materials used in the tests are taken from IELTS Listening Actual Test Vol. 2. Due to the current curriculum of second-year English majors at HaUI, both tests include 20 questions of which first 10 questions are from section 1 and 10 questions left are in section 2 of IELTS listening tests. The type of questions in two tests is nearly similar to each other, in which section 1 is featured with filling the words the blanks and the section 2 is multiple choices. To evaluate which group did show the sign of improvement, the results of the tests were analyzed by an analysis of covariance (SPSS). As for interview, participants in the experimental groups who were labelled S1 to S5 were asked to assess the feasibility of shadowing practice, especially the at-home procedure.

Both groups in the study are at their $3^{\text {rd }}$ semester, following the curriculum for full-time training at class with the book Skillful Listening and Speaking 2 by David Bohlke \& Robyn Brinks Lockwood, 2013 [14]. Only students in the experimental group attended shadowing class with the authors. The materials used were audios in DVD 1 from the book Effortless English by A.J. Hoge [15]. The suitability of the materials into the study follows a handful of factors. Firstly, the average number of academic words appearing in each audio was around ten. Secondly, the average duration of an audio was one minute and a half. Finally, the average number of words spoken in a second was 2-3 words per second. Meanwhile, the current English level of students in the study is nearly B1 (CEFR) which is totally compatible to the difficulty of the audios. 


\subsection{Procedures for data collection and analysis}

For in-class shadowing practice, the authors followed the Hamada's procedure because his procedure completely fits in this study regarding to one-month experiment.

Table 1. Procedure of Hamada [12]

\begin{tabular}{ll}
\hline Step & Procedure \\
\hline 1. Dictation cloze & Fill in the blanks of written scripts \\
2. Mumbling & Silently shadowing the incoming sounds without texts \\
3. Parallel reading & Shadowing while reading the text of passage \\
4. Check understanding & Check with the texts written both in English and Vietnamese for three minutes \\
5. Shadowing & Shadow three times \\
6. Check details & Check with the written texts for three minutes for sounds one could not hear \\
7. Content shadowing & or shadow, and meanings one could not understand \\
8. Dictation cloze & Concentrate on both shadowing and interpreting the meaning of the passage \\
\hline
\end{tabular}

Twice a week, the experimental group attended the class of shadowing training in a 45-minute lesson and practiced steps as described in table 1. Accordingly, three important points should be noticed in Hamada's procedure. Firstly, these eight steps encompassed two steps (4 and 6) which comprehension checks are applied by reading alone as well as purely shadowing. Secondly, step 8 aimed to check how much students improved from the first step. Thirdly, participants tried dictation cloze in order to be more acclimatized to personal accomplishments. In the first 20-25 minutes of the class, students applied steps 1-4 to ensure they understood contents of the texts regarded as the momentum follow the next steps with ease. In the rest of the lesson, other steps were one by one implemented. The researchers also believed that this dramatically assisted the student's ability to tackle well with IELTS listening tests which typically required to fill in the blank or missing information.

Table 2. At-home shadowing procedure

\begin{tabular}{lll}
\hline \multicolumn{1}{c}{ Steps } & \multicolumn{1}{c}{ Procedure } \\
\hline 1. & Check understanding & $\begin{array}{l}\text { Listen without texts. } \\
\text { If there are some parts which are hard to hear, open the texts and read while } \\
\text { listening. }\end{array}$ \\
\hline 2. & Interpreting & Listen to a short sentence and consecutively interpret into Vietnamese \\
\hline 3. & Memorizing & $\begin{array}{l}\text { Listen to a short sentence and repeat what speaker says by catching its } \\
\text { meaning and key words }\end{array}$ \\
\hline 4. & Shadowing & Shadowing three times \\
\hline 5. & Recording & $\begin{array}{l}\text { Send the recording of steps 2, 3 and } 4 \text { to a friend in experimental group and } \\
\text { the researchers to be assessed and given advice }\end{array}$ \\
\hline
\end{tabular}

From the researchers' perspective, however, Hamada [12] did not introduce a procedure for students to practice at home leading to a big question if training shadowing at home following these steps ignites its optimal impact. Based on the personal teaching experience of the researcher, some factors should be considered. Firstly, the atmosphere at class and at home are totally different as students surrounded by friends can pay more attention with high interest. Secondly, they are also motivated to interact with others so that the optimal shadowing practice can be reached. However, practicing alone is not an easy task when students might face the prospect of getting insipid without partners. Thirdly, Hamada did not provide a clear schedule for reviewing the lessons at class when students applied shadowing at their rooms. He ignored one important fact that learning language should be followed by a constant and scientific repetition, 
which exerts a massive impact on human's memory [16]. Therefore, the researchers offered another procedure for home practicing alongside with a clear schedule.

In order to ensure that students of experimental group practiced shadowing at home with the suggested procedure (see table 2), the researchers supervised them by contacting through Facebook and Zalo day by day and strictly watching over their process of improvement.

\section{Findings and discussion}

The results were rigorously discussed and summarized as follows to find out the similarity and divergence to previous studies.

Question 1: To what extent can second-year English major students at HaUI improve their listening comprehension skill by shadowing?

The descriptive statistics of two tests for both groups (table 3) showed the mean scores, in which experimental group appeared to outpace the control group. As a result, the effectiveness of shadowing on listening comprehension skills for second-year English majors was practically substantial.

Table 3. Descriptive statistics of listening tests of experimental group and control group

\begin{tabular}{lcccc}
\hline \multicolumn{1}{c}{ Material } & Means & SD & Min & Max \\
\hline Pre-test of the experimental group & 5.71 & 0.73 & 4.5 & 7.0 \\
Post-test of the experimental group & 7.07 & 0.70 & 5.5 & 8.0 \\
Pre-test of the control group & 5.96 & 0.87 & 3.5 & 7.5 \\
Post-test of the control group & 6.25 & 0.85 & 4.0 & 7.5 \\
\hline
\end{tabular}

Although two groups did show the sign of improvement in both tests, experimental group increased their scores faster than those of control group after undergoing shadowing within a month (see table 3). Therefore, the effect of shadowing was obviously true for the students in this study. It is also noticeable that mean and maximum score of control group were even higher than their counterparts indicating the fact that participants were randomly selected. However, not all of students in experimental group successfully enhanced their listening ability when they finished one-month shadowing training. In fact, three of them did not increase their scores. One of these commented that sounds in post-tests came to him more clearly, and he could control his attention to the test even though his score decreased.

Five students in the experimental group also admitted to find challenging to catch up with the speed of the conversation while they did not frequently trained themselves with listening English at home. Intriguingly, ten among fourteen students of experimental group performed well in section 1 of post-test whose correct answers were at least 5/10. Eight of them easily dealt with the question number 11 to 13 in section 2 . Among them, two confessed that they could manage to hear the sound coming in clearer way, and they could catch up with the speed of the test alongside with the ideas of speaker.

The reasons for their greater performance could be explained by assessing the process of applying shadowing not only at class but also at home. During the time of shadowing class, two times of dictation cloze were used to partly check their understanding of the audios, mark their improvement and eventually intensify their competency of answering questions by filling in the blank. On the other hand, practicing shadowing at home accelerated the ability of catching, memorizing and summarizing information as interpretation part required them to digest the meaning of the audios, remember and finally come out by speaking out loudly.

Even though results of the study appeared to be similar to those of other studies [8] - [13], there are some distinctive points which should be cleared. In terms of similarity, all the experiments of shadowing involving the researchers' study and others set the final goal of proving its effect on listening comprehension ability. Generally, these studies displayed their 
results under descriptive statistics showing participants in experimental groups improved their listening skills. When it comes to divergence between the study and others, a host of peculiarities could be differentiated. The previous researchers merely focused on training shadowing at class while carelessly noticing the importance of home practicing. None of guidance of shadowing practice after school was introduced to students leading to a situation that they themselves might be baffled about schedules and even steps to apply this method when there was no class. From the authors' cognition, a habit is normally formed after 21 days in row of practicing, and it happens in the same mechanism to shadowing application. Without self-training in a certain timetable, the effect of shadowing could be turned into temporary if it is not intensively and repetitively used.

Contributing to a great performance of an IELTS listening test, the ability of interpreting plays a critical role to tackle with complicated sentences in the speech or conversation. Nonetheless, interpretation was not intensively presented to participants in other studies as contents of materials used by researchers came from TOIEC books or daily conversation audios hence their lexicon and grammar were not as intricate as that of IELTS books. Therefore, the researchers suggested students to interpret audios into Vietnamese so that they could actively control their understanding of the lessons as well as consequently the content of IELTS listening test.

Question 2: What are students' attitudes towards in-class and at-home shadowing procedures?

The results from the interview with 5 students in experimental group drew a picture on their shadowing practice in class and at home. All of them affirmed that they strictly followed the instruction of the researchers in class. However, one admitted that they sometimes ignored the athome procedure. Interestingly, 3 out of 5 students including S3, S4 and S5 practiced in a group actively at home with TED talk on YouTube. S1 shared that at-home shadowing procedure help him understand the text and make acquainted with interpreting duty. All interviewees agreed that shadowing increased their listening comprehension including S2 whose post-test score remain unchanged compared to the pre-test. Four out of five expressed the ambition to enhance shadowing practice in the next semesters. However, 2 students including S2 and S5 found interpreting step in the suggested at-home shadowing procedure really difficult. This is understandable because they are just sophomores and interpreting requires more skills and practice. That is the anticipated situation as one author in this study has been teaching interpreting and translation at HaUI for years. The interview result partially proved that students had positive attitudes towards application of shadowing in their learning habit. They were rather eager to apply in-class and at-home shadowing procedures.

By observing shadowing activities at lab room in class, the authors saw students' willingness and active engagement into lessons of shadowing practice. All of them followed the guidelines and put their efforts in lesson. Most students showed their awareness of at-home shadowing practice to enhance listening comprehension skill.

\section{Conclusion}

The findings revealed that shadowing application was useful in improving English listening comprehension for sophomore at FFL, HaUI. Therefore, the authors did expect to raise concern among English language teachers at her faculty. By correctly applying shadowing as a learning tactic or measure, students will surely be able to promote their listening comprehension skill which is noticed as a top priority in learning a language, further to create the momentum to attain impressive speaking skills, and especially to cope with the high difficulty of interpretation subjects when they turn into seniors without being sweaty. In addition, the study found that students showed their positive attitudes towards applying shadowing in lessons in class and activities at home. Therefore, it is advisable to have synchronous application for students at FFL, HaUI in the next semesters. 
However, some shortcomings from this study were recognized due to some limitations of research time and participants. One-month study did not allow researchers to conduct an experiment on more than 28 participants as well as select various learning materials. As the result, the study did not go to prove either challenging or less challenging listening materials were more effective when applying shadowing. Last but not least, the at-home shadowing practice was suggested based on the researcher's teaching experience without consultancy from other researchers. Those hopefully open doors to further research in the coming time.

\section{REFERENCES}

[1] A. Anderson and T. Lynch, Listening. New York: Oxford University Press, 1988.

[2] M. Rost, Teaching and Researching Listening, second edition. UK: Pearson Longman Publisher, 2013.

[3] B. M. Azmi, B. Celik, N. Yidliz, and M. C. Turgul, "Listening Comprehension Difficulties Encountered by Students in Second Language Learning Class," Journal of Education and Instructional Studies in the World, vol. 4, pp.1-6, 2014.

[4] S. Lambert, "Shadowing," Meta, vol. 37, no. 2, pp. 263-273, 1992.

[5] Y. Hamada, "Improvement of Listening Comprehension Skills through Shadowing with Difficult Materials," The Journal of Asia TEFL, vol. 8, pp. 139-162, 2011.

[6] K. Tamai, "The effectiveness of shadowing and listening process," Current English Studies, vol. 36, pp. 105-116, 1997.

[7] S. Kadota, Science of shadowing and oral reading. Tokyo: Cosmopier Publishing Company, 2007.

[8] S. Katoda and K. Tamai, English shadowing. Tokyo: Cosmopier Publishing Company, 2005.

[9] S. Kato, "Listening activities for the acquisition of Aviation English proficiency test," Bulletin of Chiba University Language and Culture, vol. 3, pp. 47-59, 2009.

[10] T. Oki, "The role of latency for word recognition in shadowing," Annual Review of English Language Education in Japan, vol. 21, pp. 51-60, 2010.

[11] H. Mochizuki, "Application of shadowing to TEFL in Japan: The case of junior high school students," Studies in English Language Teaching, vol. 29, pp. 29-44, 2006.

[12] Y. Hamada, "An effective way to improve listening skills through shadowing," The Language Teacher, vol. 26, pp. 3-10, 2012.

[13] Y. Hamada, "Uncovering shadowing as an EFL teaching technique for listening learners' perception, self-confidence and motivation," Annual Research Report on General Education, Akita University, vol. 17, pp. 9-22, 2015.

[14] D. Bohlke and R. B. Lockwood, Skillful Listening and Speaking 2. MacMilan, 2013.

[15] A. J. Hoge, Effortless English. Effortless English LLC, 2014.

[16] D. L. Hintzman, "How does repetition affect memory? Evidence from judgments of recency," Memory \& Cognition, vol. 38, pp. 102-115, 2010. 